medRxiv preprint doi: https://doi.org/10.1101/2021.03.24.21253842; this version posted March 26, 2021. The copyright holder for this preprint (which was not certified by peer review) is the author/funder, who has granted medRxiv a license to display the preprint in All rights reserved. No reuse allowed without permission.

\title{
Gender Differences in Caries and Periodontal Status in UK Children
}

\section{Sofia Papadaki ${ }^{1,2}$, Gail V A Douglas ${ }^{1}$, Alaa HaniBani ${ }^{1}$, Jing Kang ${ }^{1, *}$}

${ }^{1}$ School of Dentistry, University of Leeds, LS2 9LU, Leeds, UK

${ }^{2}$ Dental Core Trainee at the James Cook University Hospital, TS4 3BW, Middlesbrough, UK

*CORRESPONDING AUTHOR:

Jing Kang, E-mail: J.Kang@leeds.ac.uk

Word Count: (Pages 3-9): 2174

Abstract Word Count: 320

Figure: One (1)

Tables: Three (5)

Author contribution statement: All authors substantially contributed to the conception and design of this study, drafting and revising the article critically, and final approved the version. SP and JK particularly performed the data acquisition, analysis, and interpretation.

All authors declare no conflict of interest. 
medRxiv preprint doi: https://doi.org/10.1101/2021.03.24.21253842; this version posted March 26, 2021. The copyright holder for this preprint (which was not certified by peer review) is the author/funder, who has granted medRxiv a license to display the preprint in All rights reserved. No reuse allowed without permission.

\begin{abstract}
Background

Gender inequalities in dental caries and periodontal diseases have been observed among adults. However, literature is scarce for children and evidence on gender inequalities regarding caries and/or periodontal diseases is vague. Our aim is to examine potential gender differences in UK children regarding caries experience and periodontal status using data from the UK's 2013 Children's Dental Health Survey (CDHS).
\end{abstract}

\title{
Methods
}

CDHS included children aged 5, 8, 12 and 15 years. Their dental caries experience and periodontal status were reported using the number of decayed, missing and filled teeth (DMFT or dmft for permanent or primary dentition at both D1 and D3 thresholds) and the basic periodontal examination (BPE) score, respectively. Zero-inflated negative binomial (ZINB) models were used to fit DMFT/dmft and a multinomial logistic regression (MLR) model was used for BPE scores after adjustment for possible confounding factors, to assess the gender inequality on DMFT/dmft and BPE in the UK children.

\section{Results}

The analyses included 9,866 children. No gender inequalities in caries experience were observed in the 5 and 8-year-old children regardless of the threshold at which dental caries were examined. However, for the 12- and 15-year-old adolescents, females had higher D 3 MFT scores compared to males (IRR: 1.28 , 95\% CI: 1.10-1.49 and IRR: $1.16,95 \%$ CI: 1.00-1.35, respectively). Additionally, the 15-year-old females had lower probability to be caries free (OR: 0.59, 95\% CI: 0.45-0.82), regardless of the threshold at which dental caries were examined. With regards to the periodontal status, no statistically significant gender inequalities $(\mathrm{p}>0.05)$ were observed.

\section{Conclusions}

In the UK, female adolescents had experienced more carious lesions compared to males of the same age group, when dental caries were examined into dentine (D3MFT). However, 15year-old males matched females in their caries experience, when the early enamel lesions were included in caries diagnosis $\left(\mathrm{D}_{1} \mathrm{MFT}\right)$. With regard to the periodontal status, no gender 
medRxiv preprint doi: https://doi.org/10.1101/2021.03.24.21253842; this version posted March 26, 2021. The copyright holder for this preprint (which was not certified by peer review) is the author/funder, who has granted medRxiv a license to display the preprint in

All rights reserved. No reuse allowed without permission.

dissimilarity was confirmed among British adolescents. The increased risk of adolescent females to dental caries may signify additional needs for prevention and improved oral care.

KEY WORDS (MESH verified): caries, periodontal, gender inequality, children's dental health survey 
medRxiv preprint doi: https://doi.org/10.1101/2021.03.24.21253842; this version posted March 26, 2021. The copyright holder for this preprint (which was not certified by peer review) is the author/funder, who has granted medRxiv a license to display the preprint in All rights reserved. No reuse allowed without permission.

\section{Introduction}

Gender inequalities in dental caries and periodontal diseases among adults have been investigated widely. Many studies showed that females bear a higher burden of dental caries ${ }^{1}$, while males were found to be more susceptible to develop advanced periodontal disease ${ }^{2}$. However, evidence in the field of paediatric dentistry remains rather unclear, as conclusions from various studies are mixed and contradictory. Some published literature depicted gender bias regarding caries experience for juvenile patients, with females being reported as more susceptible ${ }^{3-8}$. On the other hand, there are studies supporting an opposite trend, indicating that males, especially at the primary dentition stage, exhibit higher caries experience than females of the same age ${ }^{9-12}$. Moreover, some studies found no significant $(p>0.05)$ gender inequalities in caries experience ${ }^{13-17}$.

For periodontal diseases, most literature suggests that male teenagers are more likely to develop gingivitis and have suboptimal oral hygiene ${ }^{18-21}$. However, some studies report the absence of significant gender inequalities in the periodontal status of children ${ }^{22-24}$.

Evidence around gender inequalities is as yet incomplete, with limitations including biased sampling, small sample size and methodological flaws. Therefore, this study aims to add information by examining potential differences in caries experience and periodontal status between genders using the UK 2013 Children's Dental Health Survey (CDHS) data, a large and robust epidemiological survey. It is noteworthy that the CDHS is the first survey in the UK that measures caries at the D1 threshold. This novelty makes the current study interesting in that both enamel and dentine caries were measured. An affirmation of gender inequalities in children's oral health is important, as this would stimulate further studies in order for the real cause of this assumption to be identified and therefore addressed.

\section{Material and methods}

\section{Data source}

The 2013 CDHS was used as the data source, including children from England, Wales and Northern Ireland. Data were collected through clinical examinations by calibrated dental teams, questionnaires completed by the 12- and 15-year-old pupils and parent questionnaires of those children who participated in the study ${ }^{25}$. The target populations were the 5-, 8-, 12and 15-year-old children, representing the primary (5-year-old), mixed (8-year-old) and permanent dentition (12- and 15-year-old) ${ }^{25}$. 
medRxiv preprint doi: https://doi.org/10.1101/2021.03.24.21253842; this version posted March 26, 2021. The copyright holder for this preprint (which was not certified by peer review) is the author/funder, who has granted medRxiv a license to display the preprint in

All rights reserved. No reuse allowed without permission.

Ethical approval for CDHS was gained by the University ethics committee at the University College London (Project ID 2000/003) and participants had consented in advance for the use of data in future research projects.

\section{$\underline{\text { Outcome measures }}$}

There were two dental outcome measures:

1) Children's dental caries experience based on DMFT/dmft scores

2) Periodontal status using the available BPE scores

Children's dental caries experience was measured at two different thresholds: including enamel lesions (D1) and lesions only into dentine (D3). The CDHS was novel in measuring caries at the D1 threshold. Table 1 and Figure 1 demonstrates the differences of these two caries thresholds.

The periodontal status was measured based on BPE scores (Table 2), which were only available for the 15-year-old children.

\section{Exposure}

Gender was the main exposure measure.

\section{Covariates}

Covariates included participants' demographic characteristics such as age (scale) and socioeconomic status (SES; quantiles 1-5) ${ }^{26}$, their dietary habits such as consumption of water or food and drinks containing sugar including cakes, biscuits, sweets, fruit juice, smoothies, energy and fizzy drinks (less than once a day, more than twice a day), their oral hygiene practices such as tooth brushing frequency (less than once a day, more than twice a day), tooth flossing (yes, no) and pattern of dental attendance patterns ${ }^{27}$ (only when have problems arise, routinely), experience of orthodontic treatment (yes, no), as well as dental anxiety levels (low, medium, high) $)^{28,29}$.

More covariates were also examined, such as children's experience of prevention (fissure sealants, fluoride varnish) and use of fluoride toothpaste. However, those covariates that were available for only a small number of participants or did not reach the set significance level at 
medRxiv preprint doi: https://doi.org/10.1101/2021.03.24.21253842; this version posted March 26, 2021. The copyright holder for this preprint (which was not certified by peer review) is the author/funder, who has granted medRxiv a license to display the preprint in

All rights reserved. No reuse allowed without permission.

$0.5^{30}$ were not included in the multivariable analysis for the adjustment of the ZINB and MLR models.

\section{Statistical Analysis}

Descriptive statistics was performed for comparisons between males and females. The zeroinflated negative binomial models (ZINB) were used to fit the $\mathrm{D}_{1} \mathrm{MFT} / \mathrm{d}_{1} \mathrm{mft}$ and $\mathrm{D}_{3} \mathrm{MFT} / \mathrm{d}_{3} \mathrm{mft}$ scores, as it was indicated by the DMFT/dmft distribution, with more than half of children having a DMFT/dmft score equal to zero. ZINB model is a two-part model, with the zero-inflated part estimating the chance of excessive zeros, and the count model the number of DMFT/dmft. The confidence interval (CI) was set to $95 \%$ after sampling weight. Adjustments for demographic features, oral hygiene practices, dietary habits and dental anxiety were included in the models gradually. This led to three different statistical models from a univariate to a multivariate approach to demonstrate the robustness of the results. The mo model was unadjusted comparing the $\mathrm{D}_{1} \mathrm{MFT} / \mathrm{d}_{1} \mathrm{mft}$ and $\mathrm{D}_{3} \mathrm{MFT} / \mathrm{d}_{3} \mathrm{mft}$ differences between genders without taking into consideration other possible confounders.

The $\mathrm{m}_{1}$ model was adjusted for demographic features.

The $\mathrm{m}_{2}$, which applied only for the D1MFT and D 3 MFT variables, was adjusted for the above-mentioned covariates, including children's SES, dental behaviour, dietary habits and dental anxiety.

This happened as a result of limited information about the 5- and the 8-year-old children with regards to their oral hygiene and dietary habits.

Additionally, subgroup statistical analysis to estimate children's caries experience in each age group was performed. The subgroup analysis referred to the 5-, 8-, 12- and 15-year-old children, respectively.

With regards to periodontal status, data were analysed using the Multinomial Logistic Regression (MLR) model at four different levels [level 1, or reference level (BPE:0), level 2 (BPE:1), level 3 (BPE:2) and level 4 (BPE:3 or 4)], with the aim to compare each group (levels 2, 3,4) with reference level (Table 2). The model was sequentially adjusted for SES, oral hygiene practices, including frequency of toothbrushing, flossing, dental attendance pattern, and experience of orthodontic treatment ${ }^{31}$.

Data were weighed according to primary sampling unit (PSU) and strata, and then, analysis was performed using R studio with Survey Package and StataSE 14.

\section{Results}


medRxiv preprint doi: https://doi.org/10.1101/2021.03.24.21253842; this version posted March 26, 2021. The copyright holder for this preprint (which was not certified by peer review) is the author/funder, who has granted medRxiv a license to display the preprint in

All rights reserved. No reuse allowed without permission.

In total, 9,866 children were included in the analyses. A comparison of different covariates between genders is presented in Table 3 .

For dental caries comparison between male and females, no differences were found in 5- and 8-year-old children at either caries threshold. Among 12-year-old children, females were associated with higher DMFT scores, regardless of the threshold at which dental caries was diagnosed [IRR (D3): 1.28, 95\%CI (1.10-1.49), p<0.01 and IRR(D1): 1.22, 95\% CI (1.101.35), $\mathrm{p}<0.001]$. The discrepancy in caries experience between genders was evident among 15-year-old children too, but only at the dentinal threshold [IRR (D1): 1.16, 95\% CI (1.001.35), $\mathrm{p}<0.05]$. Also, the possibility for 15-year-old females to be "caries-free" (DMFT:0) was lower compared to males [OR(D3):0.59, 95\% CI (0.45-0.82), p<0.01 and OR(D1):0.55, 95\% (0.41-0.74), $\mathrm{p}<0.001]$, regardless of threshold at which dental caries was examined. However, when caries experience was estimated including early enamel lesions (D 1 MFT), males matched females in caries experience (Table 4).

The results of the MLR model are summarised in Table 5, comparing the periodontal status of the 15-year-old females and males. No significant difference ( $p>0.05)$, for any of the examined BPE scores, was noted between genders.

\section{Discussion}

No gender inequalities in either disease was noted at the primary dentition stages. A potential explanation of the absence of caries inequalities could be that children of such young age cannot opt for their dietary habits nor are responsible for their daily oral hygiene. Therefore, the most important risk factors are influenced directly by parents or guardians, which could demarcate the absence of gender susceptibility to dental caries. Notably, the majority of studies are in line with the lack of significant gender discrepancy regarding dental caries experience in the primary dentition ${ }^{13,16,32,33}$. However, it would be prudent not to draw such conclusion due to lack of data on eating habits and oral hygiene practices for these age groups.

For the permanent dentition, the outcomes were substantial. Females in the 12-year-old group, had higher $\mathrm{D}_{1} \mathrm{MFT}$ and $\mathrm{D}_{3} \mathrm{MFT}$ scores. This susceptibility of females was confirmed among the 15-year-old adolescents too, but only when disease was diagnosed into dentine (D3MFT). When early enamel lesions were included in caries diagnosis, the 15-year-old males matched females in caries experience, which denotes that the caries experience of males comprised of more enamel lesions than females. 
medRxiv preprint doi: https://doi.org/10.1101/2021.03.24.21253842; this version posted March 26, 2021. The copyright holder for this preprint (which was not certified by peer review) is the author/funder, who has granted medRxiv a license to display the preprint in All rights reserved. No reuse allowed without permission.

According to pupil questionnaires, female adolescents consumed sweets and sugary soft drinks less frequently, while they used to brush their teeth more frequently. Ideally, this should have materialised in less exposure to caries. However, higher prevalence of caries among females may be associated with erroneous assumptions on healthy and balanced diet from a dental perspective. It could be hypothesised that participants may have underestimated the daily consumption of hidden sugars with exponential cariogenic risk ${ }^{34-36}$. Another explanation of the higher female susceptibility may be associated with the earlier tooth eruption and, therefore, longer exposure to cariogenic products in the oral cavity ${ }^{37}$. Also, a number of genome-wide-association-studies (GWAS), support that gender differences may be attributed to a number of gene variations influencing the oral environment, enamel formation, dietary preferences and composition of pathogenic bacteria ${ }^{1,38,39}$. Furthermore, differences in saliva composition and in overall saliva flow rate could stem from hormonal changes due to puberty onset ${ }^{40}$, pregnancy or menstruation, rendering female adolescents more prone to dental caries ${ }^{10,41}$. Among physiological variations between genders, elevated oestrogen levels in females have been associated with changes in saliva composition and reduction in the salivary flow. These conditions in combination with a cariogenic diet could contribute to caries incidence among female adolescents ${ }^{42}$.

Although there is no consensus regarding the existence of specific gender inequalities in caries experience for the permanent dentition of adolescents, a number of studies ${ }^{3,5,8,43}$ were in accordance with our findings.

Multiple studies ${ }^{22,23,44}$ were in agreement with the absence of gender discrepancies with regard to the periodontal status of the 15-year-old adolescents based on BPE scores. In contrast, other studies ${ }^{9,10,13,14}$ reported that males had worse gingival or periodontal status than females. The reported susceptibility of male adolescents to poorer periodontal/gingival status, may stem from suboptimal oral hygiene regime rather than the genetic superiority of females. Also, notable deviations in study design, sample selection and indexes used do not allow comparisons or concrete conclusions to be drawn.

The high-quality dataset derived from the 2013 CDHS offers the opportunity for comprehensive analysis of children's oral health ${ }^{15}$ and serves as a strength of this study. Also, the different thresholds at which dental caries diagnosis was estimated are reflected eloquently in the present study, eliminating the risk of confusion or result deviations and allowing comparisons between different outcomes. Another strength refers to the ZIBN 
medRxiv preprint doi: https://doi.org/10.1101/2021.03.24.21253842; this version posted March 26, 2021. The copyright holder for this preprint (which was not certified by peer review) is the author/funder, who has granted medRxiv a license to display the preprint in All rights reserved. No reuse allowed without permission.

model used to investigate caries experience, which is the most reliable and appropriate statistical approach according to DMFT/dmft distribution ${ }^{45}$.

There are also limitations. A number of factors may mean that CDHS underestimates the true population levels of oral disease. As with most surveys, CDHS was based solely on clinical examination, and epidemiological convention calibrates examiners to "underdiagnose" the presence of dental caries in case of uncertain diagnosis ${ }^{15}$. Also, the BPE index may underestimate periodontal disease ${ }^{46}$. Additionally, children attending special schools, where oral disease levels may be higher, were not included in the CDHS which may have underestimated the burden of such oral diseases among British children ${ }^{47,48}$. A further limitation is that self-report of dietary habits for the 12- and 15-year-old groups may have underestimated the consumption of cariogenic food and drinks. The dietary data being limited to these age groups also means that the ZINB model was not adjusted for those factors for the 5- or 8-year-old groups, which may have rendered the estimations of the $\mathrm{d}_{3} \mathrm{mft}$ and $\mathrm{d}_{1 \mathrm{mft}}$ more susceptible to errors. Furthermore, BPE data were only available for the 15-year-old group, rendering comparisons between age groups impossible.

In this study, the first to report on gender inequalities using a large UK dataset which includes both enamel and dentine caries, it is notable that female adolescents were more susceptible to dental caries, when disease examined into dentine ( $\left.{ }_{3} M F T\right)$. When early enamel lesions included in dental caries diagnosis ( $\left.\mathrm{D}_{1} \mathrm{MFT}\right), 15$-year-old males matched females in their caries experience. These findings suggest that caries experience of males comprised of more enamel lesions and therefore, gender discrepancy at younger ages or when caries examined into dentine only, may be contributed to the earlier tooth eruption in girls. With regard to periodontal status, no gender inequalities were noted among British adolescents.

Despite the current findings, more prospective studies would be required to ascertain accurate conclusions, before stricter preventative measures are recommended for either of genders. Additionally, further investigation on the possible impact of the individual regional water fluoridation scheme may have in children's caries experience, would be useful. This investigation could probably reflect the need for further preventative measures, like the artificial water fluoridation in more areas across the UK. With respect to children's periodontal status, more prospective studies along with the usage of a widely agreed index, 
medRxiv preprint doi: https://doi.org/10.1101/2021.03.24.21253842; this version posted March 26, 2021. The copyright holder for this preprint (which was not certified by peer review) is the author/funder, who has granted medRxiv a license to display the preprint in All rights reserved. No reuse allowed without permission.

would be useful in investigating the potential for advanced periodontal treatment needs among children of different ages.

Conflict of interest and sources of funding: None of the authors have any conflict of interest. The study was supported solely by the authors' institution.

Acknowledgements: We would also like to thank Ioannis Pilalas for his contribution in this publication. 
medRxiv preprint doi: https://doi.org/10.1101/2021.03.24.21253842; this version posted March 26, 2021. The copyright holder for this preprint (which was not certified by peer review) is the author/funder, who has granted medRxiv a license to display the preprint in All rights reserved. No reuse allowed without permission.

Figure 1. Illustration of the differences between $\mathrm{D}_{1} \mathrm{MFT} / \mathrm{d}_{1} \mathrm{mft}$ (including enamel and dentine lesions) and $\mathrm{D}_{3} \mathrm{MFT} / \mathrm{d}_{3} \mathrm{mft}$ (dentine lesions only) ${ }^{49}$.

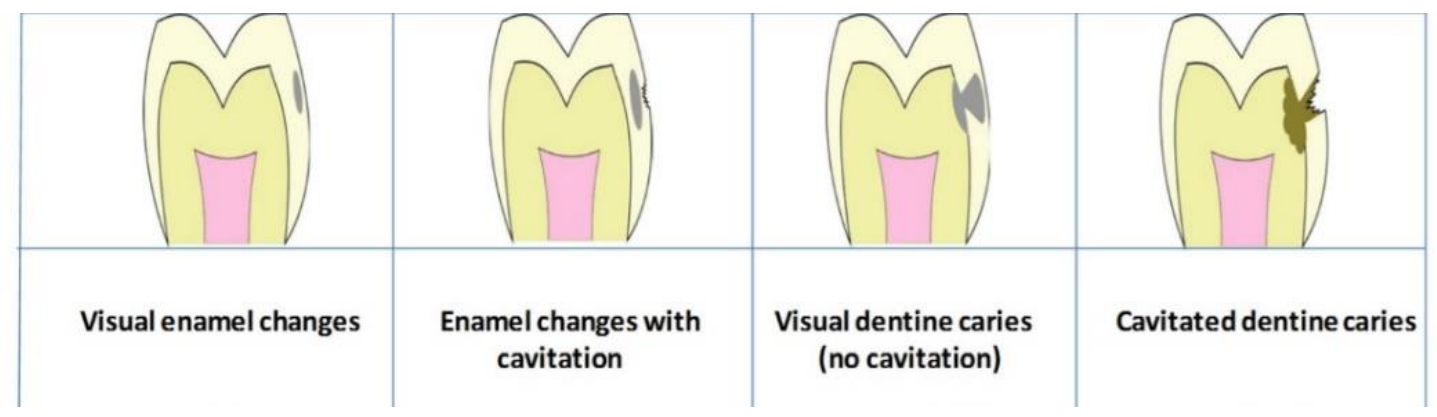

Table 1. Explanation of differences between $\mathrm{D}_{1} \mathrm{MFT} / \mathrm{d}_{1} \mathrm{mft}$ (enamel lesions) and $\mathrm{D}_{3} \mathrm{MFT} / \mathrm{d}_{3} \mathrm{mft}$ (dentine lesions).

\section{$\mathrm{D}_{1} \mathrm{MFT} / \mathrm{d}_{1} \mathrm{mft}$}

Decayed teeth including early enamel lesions along with dentinal caries

Missing teeth due to caries

Filled teeth

\section{$\mathrm{D}_{3} \mathrm{MFT} / \mathbf{d}_{3} \mathbf{m f t}$}

Decayed teeth, including caries lesions into dentine only Missing teeth due to caries

Filled teeth

Table 2. BPE scores and levels in multiple regression analysis.

\section{Levels BPE scores}

\begin{tabular}{l|ll}
\hline Level 1 & 0 & No bleeding \\
Level 2 & 1 & Bleeding on probing \\
Level 3 & 2 & Bleeding with retentive factors, such as calculus \\
Level 4 & 3 & Bleeding with shallow pockets between $3.5-$ \\
& & $5.5 \mathrm{~mm}$ \\
& 4 & Deep pockets $>5.5 \mathrm{~mm}$
\end{tabular}


medRxiv preprint doi: https://doi.org/10.1101/2021.03.24.21253842; this version posted March 26, 2021. The copyright holder for this preprint (which was not certified by peer review) is the author/funder, who has granted medRxiv a license to display the preprint in All rights reserved. No reuse allowed without permission.

Table 3. Comparison between male and female participants in 2013 CDHS. N=9866.

N
Demographics
Age group
5-year-old
8-year-old
12-year-old
15-year-old
HMRC quintile
1 (Most deprived)
2
3
4
5 (Least deprived)

Male Female p-value

\section{Oral hygiene practices}

Frequency of brushing teeth

Twice a day or more

Less than twice a day

$4812(48.8) \quad 5054(51.2)$

0.496

$1264(26.3) \quad 1285(25.4)$

$1171(24.3) \quad 1196(23.7)$

$1222(25.4) \quad 1310(25.9)$

1155 (24.0) $1263(25.0)$

$1432(30.9) \quad 1669(34.5)$

1062 (22.9) $1144(23.7)$

$952(20.6) \quad 903(18.7)$

$710(15.3) \quad 671(13.9)$

$473(10.2) \quad 448(9.3)$

Used dental floss in the last year $=$ No

Pattern of dental attendance = Only when in trouble/never

\section{Orthodontic treatment experience}

Ever had bracket fitted or adjusted $=$ No

$1493(88.9) \quad 1446(83.1) \quad<0.001$

\section{Dietary habits}

Frequency of eating cakes or biscuits

Twice or more a day

Once or less a day

$\begin{array}{lll}1652(80.8) & 1765(85.1) & \\ 393(19.2) & 310(14.9) & \\ 1000(80.6) & 1013(76.1) & 0.006 \\ 428(18.3) & 432(17.1) & 0.28 \\ & & \\ 1493(88.9) & 1446(83.1) & <0.001 \\ & & 0.018\end{array}$

$1040(44.8) \quad 1024(40.5)$

$1280(55.2) \quad 1506(59.5)$

Frequency of eating sweets

Twice or more a day

Once or less a day 
medRxiv preprint doi: https://doi.org/10.1101/2021.03.24.21253842; this version posted March 26, 2021. The copyright holder for this preprint (which was not certified by peer review) is the author/funder, who has granted medRxiv a license to display the preprint in All rights reserved. No reuse allowed without permission.

Frequency of drinking soft drinks

$<0.001$

containing sugar

Twice or more a day

Once or less a day

$854(37.1) \quad 845(33.5)$

1451 (62.9) $1674(66.5)$

Frequency of drinking energy drinks

Twice or more a day

Once or less a day

$416(18.1) \quad 354(14.2)$

$1886(81.9) \quad 2141(85.8)$

Frequency of drinking fizzy drinks

Twice or more a day

Once or less a day

Frequency of drinking water

Twice or more a day

Once or less a day

$1103(47.3) \quad 1062(41.8)$

$1225(52.7) \quad 1476(58.2)$

$1631(70.7) \quad 1810(71.9)$

$675(29.3) \quad 706(28.1)$

\section{$\underline{\text { Dental anxiety }}$}

Self-rated dental anxiety score

Low/no anxiety

Moderate anxiety

Extreme anxiety

\section{$\underline{\text { Dental health outcomes }}$}

$\mathrm{d}_{3} \mathrm{mft}$ (mean (SD))

$\begin{array}{lll}0.8(1.8) & 0.7(1.6) & <0.001 \\ 0.9(1.9) & 1.1(2.2) & <0.001\end{array}$

$\mathrm{D}_{3} \mathrm{MFT}$ (mean (SD))

$\mathrm{d}_{1 \mathrm{mft}}($ mean (SD))

$1.2(2.2)$

$1.0(2.1)$

0.001

DiMFT (mean (SD))

$1.7(3.0)$

$1.9(3.1)$

0.012

\section{$\underline{\text { BPE }(\mathbf{N} \%)}$}

$$
\begin{aligned}
& 0(\mathrm{~N} \%) \\
& \neq 0(\mathrm{~N} \%)
\end{aligned}
$$

$\begin{array}{ll}935(40.9) & 576(23.4) \\ 1172(51.2) & 1461(59.5) \\ 181(7.9) & 420(17.1)\end{array}$

$<0.001$

$$
<0.001
$$

$<0.001$

$<0.001$

0.849

$530(49.8) \quad 581(51.4) \quad>0.05$

$534(50.2) \quad 550(48.6) \quad>0.05$ 
medRxiv preprint doi: https://doi.org/10.1101/2021.03.24.21253842; this version posted March 26, 2021. The copyright holder for this preprint (which was not certified by peer review) is the author/funder, who has granted medRxiv a license to display the preprint in All rights reserved. No reuse allowed without permission.

Note: Data are presented as frequency (\%) unless specified. Numbers may not sum to totals due to missing values; percentage may not sum to 100 due to rounding.

Deprivation index was grouped in quintiles as follows:

1 (most deprived, ranks 1-6496), 2 (ranks 6497-12993), 3 (ranks 12994-19489), 4 (ranks 19490-25986), 5 (least deprived, ranks 25987-32482)

P-value was for comparing characteristics between male and female.

SD: standard deviation 
medRxiv preprint doi: https://doi.org/10.1101/2021.03.24.21253842; this version posted March 26, 2021. The copyright holder for this preprint (which was not certified by peer review) is the author/funder, who has granted medRxiv a license to display the preprint in All rights reserved. No reuse allowed without permission.

Table 4. Dental caries experience between females and males (females vs males).
Age
$\mathrm{m}_{0}$
$\mathrm{m}_{1}$
$\mathrm{m}_{2}$

(years)

8

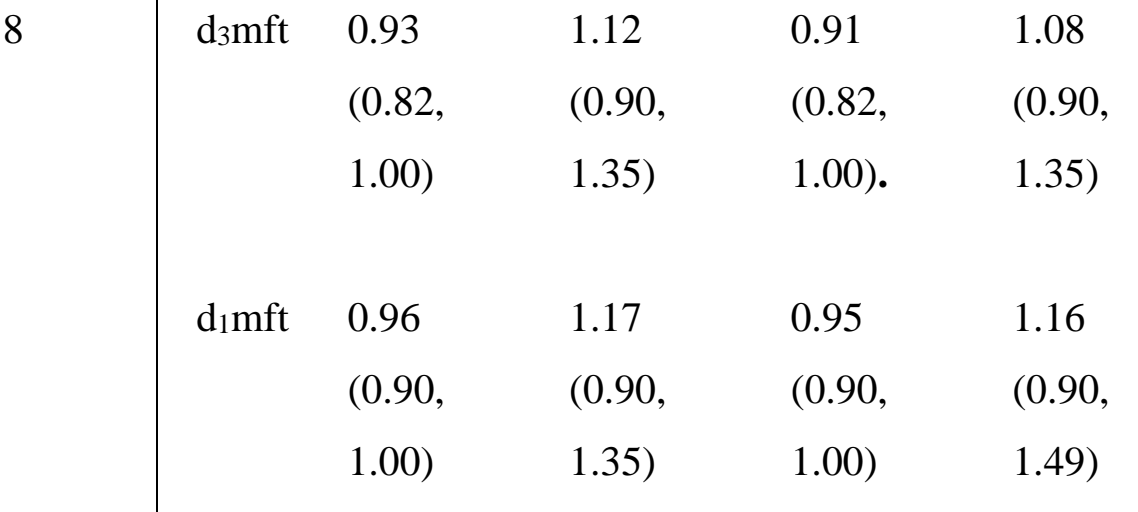

$\begin{array}{lllll}\text { NB, IRR } & \text { ZI, OR } & \text { NB, IRR } & \text { ZI, OR } & \text { NB } \\ (95 \% \text { CI }) & (95 \% \text { CI }) & (95 \% \text { CI }) & (95 \% \text { CI }) & \end{array}$

$\mathbf{Z I}$

$(0.82, \quad(0.90, \quad(0.82, \quad(0.90$,

1.10) 1.35) 1.10) 1.35)

\begin{tabular}{|c|c|c|c|c|c|c|}
\hline & $\begin{array}{l}\text { NB, IRR } \\
(95 \% \mathrm{CI})\end{array}$ & $\begin{array}{l}\text { ZI, OR } \\
(95 \% \mathrm{CI})\end{array}$ & $\begin{array}{l}\text { NB, IRR } \\
(95 \% \mathrm{CI})\end{array}$ & $\begin{array}{l}\text { ZI, OR } \\
(95 \% \mathrm{CI})\end{array}$ & $\begin{array}{l}\text { NB, IRR } \\
(95 \% \mathrm{CI})\end{array}$ & $\begin{array}{l}\text { ZI, OR } \\
(95 \% \mathrm{CI})\end{array}$ \\
\hline \multirow[t]{3}{*}{$\mathrm{D}_{3} \mathrm{MFT}$} & 1.28 & 0.95 & 1.25 & 1.11 & 1.28 & 0.96 \\
\hline & $(1.10$ & $(0.74$ & $(1.10$ & $(0.82$ & $(1.10,1.49)$ & $(0.67,1.35)$ \\
\hline & $1.49) * * *$ & 1.22) & $1.49) * *$ & 1.49) & $* *$ & \\
\hline $\mathrm{D}_{1} \mathrm{MFT}$ & 1.12 & 1.07 & 1.12 & 1.28 & 1.22 & 1.32 \\
\hline
\end{tabular}


medRxiv preprint doi: https://doi.org/10.1101/2021.03.24.21253842; this version posted March 26, 2021. The copyright holder for this preprint (which was not certified by peer review) is the author/funder, who has granted medRxiv a license to display the preprint in

All rights reserved. No reuse allowed without permission.

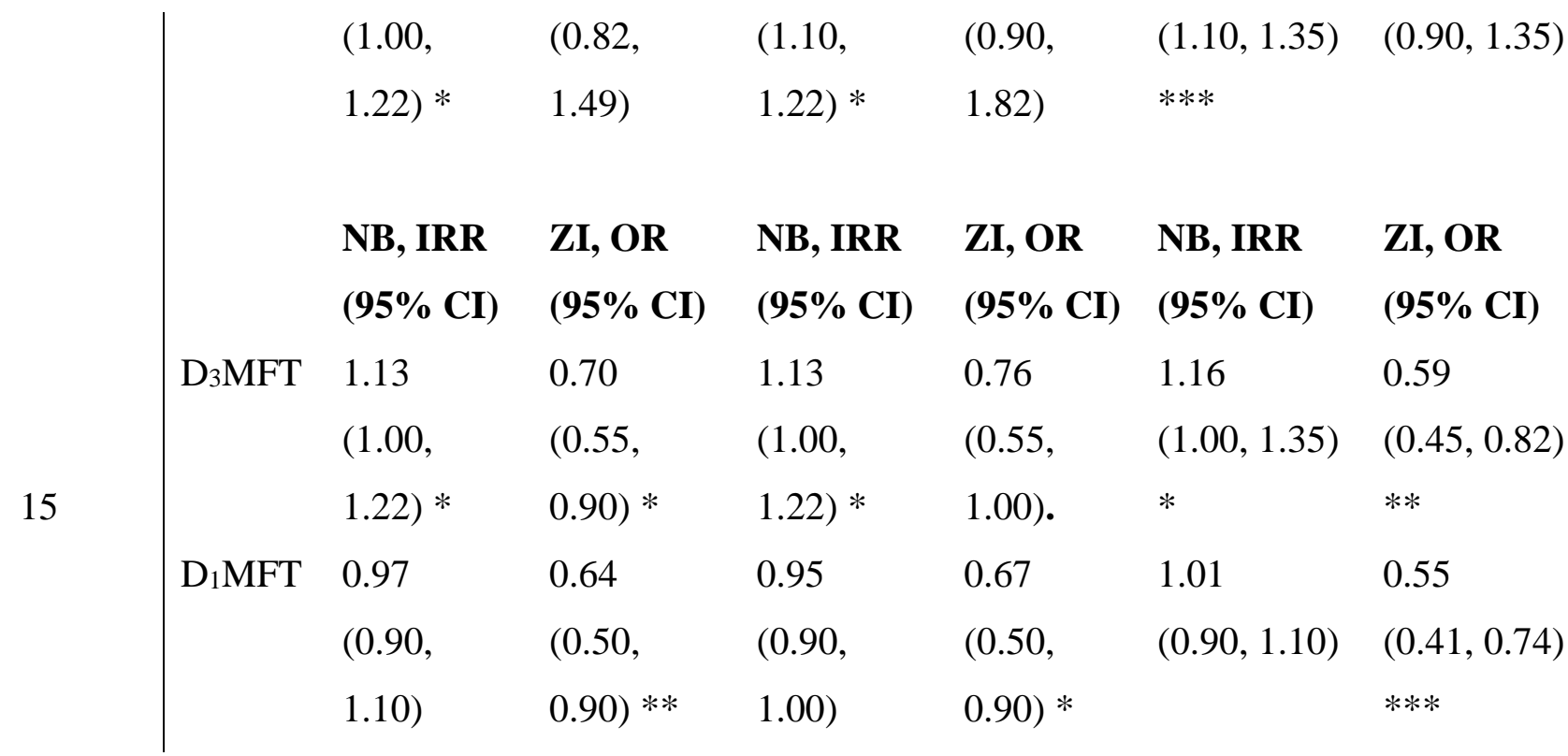

NB: Negative binomial part; Mean DMFT/dmft (2003/2013) difference between females and males with caries experience (females Vs males)

ZI: Zero-inflated part; Possibility of being caries free (females Vs males)

IRR: Incidence rate ratio

OR: Odds ratio

CI: Confidence interval

mo: Unadjusted model

$\mathrm{m}_{1}$ : Adjusted model for demographic factors (SES)

m2: Adjusted model for demographic features (SES), dental behaviour (pattern of dental

attendance and toothbrushing), dietary habits (frequency of eating cakes or biscuits, drinking fizzy drinks, energy drinks, soft drinks containing sugar and water) and dental anxiety

. $\mathrm{p}$ value $<0.1$

$* p$ value $<0.05$

$* * \mathrm{p}$ value $<0.01$

$* * * \mathrm{p}$ value $<0.001$ 
medRxiv preprint doi: https://doi.org/10.1101/2021.03.24.21253842; this version posted March 26, 2021. The copyright holder for this preprint (which was not certified by peer review) is the author/funder, who has granted medRxiv a license to display the preprint in All rights reserved. No reuse allowed without permission.

Table 5. Periodontal status between the 15-year-old females and males (females Vs males).

\begin{tabular}{|c|c|c|c|}
\hline & $\mathrm{m}_{0}$ & $\mathrm{~m}_{1}$ & $\mathrm{~m}_{2}$ \\
\hline BPE & RRR (95\% CI) & $\operatorname{RRR}(95 \% \mathrm{CI})$ & RRR (95\% CI) \\
\hline 0 (ref) & 1 & 1 & 1 \\
\hline 1 & $0.90(0.74,1.10)$ & $0.87(0.70,2.07)$ & $1.22(0.74,2.01)$ \\
\hline 2 & $0.98(0.82,1.22)$ & $0.79(0.74,1.10)$ & $0.62(0.33,1.10)$ \\
\hline 3 or 4 & $1.03(0.67,1.65)$ & $0.90(0.61,1.35)$ & $0.35(0.12,1.97)$ \\
\hline
\end{tabular}

RRR: Relative risk ratio

CI: Confidence interval

mo: Unadjusted model

$\mathrm{m}_{1}$ : Adjusted model for demographic factors (SES)

$\mathrm{m}_{2}$ : Adjusted model for demographic features and dental behaviour including the pattern of dental attendance, the frequency of tooth brushing and flossing as well as the participants' orthodontic treatment experience

. $\mathrm{p}$ value $<0.1$

$*$ p value $<0.05$

**p value $<0.01$

$* * * \mathrm{p}$ value $<0.001$ 
medRxiv preprint doi: https://doi.org/10.1101/2021.03.24.21253842; this version posted March 26, 2021. The copyright holder for this preprint (which was not certified by peer review) is the author/funder, who has granted medRxiv a license to display the preprint in All rights reserved. No reuse allowed without permission.

\section{References}

1. Lukacs JR. Sex differences in dental caries experience: clinical evidence, complex etiology. Clin Oral Investig. 2011;15(5):649-656.

2. Shiau HJ, Reynolds MA. Sex differences in destructive periodontal disease: a systematic review. J Periodontol. 2010;81(10):1379-1389.

3. Brito ACM, Bezerra IM, Cavalcante DdFB, et al. Dental caries experience and associated factors in 12-year-old-children: a population based-study. Brazilian Oral Research. 2020;34.

4. Huew R, Waterhouse PJ, Moynihan PJ, Maguire A. Prevalence and severity of dental caries in Libyan schoolchildren. Int Dent J. 2011;61(4):217-223.

5. Oliveira LBd, Moreira RdS, Reis SCGB, Freire MdCM. Dental caries in 12-year-old schoolchildren: multilevel analysis of individual and school environment factors in Goiânia. Revista Brasileira de Epidemiologia. 2015;18:642-654.

6. Perera PJ, Abeyweera NT, Fernando MP, Warnakulasuriya TD, Ranathunga N. Prevalence of dental caries among a cohort of preschool children living in Gampaha district, Sri Lanka: a descriptive cross sectional study. BMC Oral Health. 2012;12:49.

7. Shaffer JR, Wang X, McNeil DW, Weyant RJ, Crout R, Marazita ML. Genetic Susceptibility to Dental Caries Differs between the Sexes: A Family-Based Study. Caries Research. 2015;49(2):133-140.

8. Veerasamy A, Kirk R, Gage J. Epidemiology of dental caries among adolescents in Tamil Nadu, India. Int Dent J. 2016;66(3):169-177.

9. Vanobbergen J, Martens L, Lesaffre E, Bogaerts K, Declerck D. Assessing risk indicators for dental caries in the primary dentition. Community Dent Oral Epidemiol. 2001;29(6):424-434.

10. Shaffer JR, Leslie EJ, Feingold E, et al. Caries Experience Differs between Females and Males across Age Groups in Northern Appalachia. International Journal of Dentistry. 2015;2015:938213.

11. Mantonanaki M, Hatzichristos T, Koletsi-Kounari H, Papaioannou W. Sociodemographic and area-related factors associated with the prevalence of caries among preschool children in Greece. Community Dent Health. 2017;34(2):112-117.

12. Abbass MMS, Mahmoud SA, El Moshy S, et al. The prevalence of dental caries among Egyptian children and adolescences and its association with age, socioeconomic status, dietary habits and other risk factors. A cross-sectional study. F1000Res. 2019;8:8.

13. Casanova-Rosado AJ, Medina-Solís CE, Casanova-Rosado JF, Vallejos-Sánchez AA, Maupomé G, Avila-Burgos L. Dental caries and associated factors in Mexican schoolchildren aged 6-13 years. Acta Odontol Scand. 2005;63(4):245-251.

14. Saravanan S, Madivanan I, Subashini B, Felix J. Prevalence pattern of dental caries in the primary dentition among school children. Indian Journal of Dental Research. 2005;16(4):140-146.

15. Gorbatova MA, Gorbatova LN, Pastbin MU, Grjibovski AM. Urban-rural differences in dental caries experience among 6-year-old children in the Russian north. Rural Remote Health. 2012;12:1999.

16. Wyne $\mathrm{AH}$. Caries prevalence, severity, and pattern in preschool children. J Contemp Dent Pract. 2008;9(3):24-31. 
medRxiv preprint doi: https://doi.org/10.1101/2021.03.24.21253842; this version posted March 26, 2021. The copyright holder for this preprint (which was not certified by peer review) is the author/funder, who has granted medRxiv a license to display the preprint in All rights reserved. No reuse allowed without permission.

17. Nazzal H, Duggal MS, Kowash MB, Kang J, Toumba KJ. Comparison of residual salivary fluoride retention using amine fluoride toothpastes in caries-free and cariesprone children. Eur Arch Paediatr Dent. 2016;17(3):165-169.

18. Levin L, Margvelashvili V, Bilder L, Kalandadze M, Tsintsadze N, Machtei EE. Periodontal status among adolescents in Georgia. A pathfinder study. PeerJ. 2013;1:e137-e137.

19. Zhang S, Xu B, Liu J, Lo EC, Chu CH. Dental and periodontal status of 12-year-old Dai school children in Yunnan Province, China: a cross-sectional study. BMC Oral Health. 2015;15(1):117.

20. Amran AG, Alhajj MN, Al-Rafik NA. Evaluation of Gingival Health Status among 6- and 12-years-old Children in Dhamar City, Yemen: A Cross-sectional Study. J Contemp Dent Pract. 2016;17(6):440-444.

21. Elias-Boneta AR, Ramirez K, Rivas-Tumanyan S, Murillo M, Toro MJ. Prevalence of gingivitis and calculus in 12-year-old Puerto Ricans: a cross-sectional study. BMC Oral Health. 2018;18(1):13.

22. Vadiakas G, Oulis CJ, Tsinidou K, Mamai-Homata E, Polychronopoulou A. Oral hygiene and periodontal status of 12 and 15-year-old Greek adolescents. A national pathfinder survey. Eur Arch Paediatr Dent. 2012;13(1):11-20.

23. Kissa J, Chemlali S, El Houari B, et al. Aggressive and chronic periodontitis in a population of Moroccan school students. Journal of Clinical Periodontology. 2016;43(11):934-939.

24. Kang J, Smith S, Pavitt S, Wu J. Association between central obesity and tooth loss in the non-obese people: Results from the continuous National Health and Nutrition Examination Survey (NHANES) 1999-2012. J Clin Periodontol. 2019;46(4):430-437.

25. Anderson T, Thomas C, Ryan R, Dennes M, Fuller E. Children's dental health survey 2013 technical report England, Wales and Northern Ireland. London: Health and Social Care Information Centre. 2015.

26. Reisine ST, Psoter W. Socioeconomic status and selected behavioral determinants as risk factors for dental caries. J Dent Educ. 2001;65(10):1009-1016.

27. Angelillo IF, Anfosso R, Nobile CG, Pavia M. Prevalence of dental caries in schoolchildren in Italy. Eur J Epidemiol. 1998;14(4):351-357.

28. Akbay Oba A, Dülgergil CT, Sönmez IS. Prevalence of dental anxiety in 7- to 11-yearold children and its relationship to dental caries. Med Princ Pract. 2009;18(6):453457.

29. Milsom KM, Tickle M, Humphris GM, Blinkhorn AS. The relationship between anxiety and dental treatment experience in 5-year-old children. Br Dent J. 2003;194(9):503506; discussion 495.

30. Wasserstein RL, Schirm AL, Lazar NA. Moving to a World Beyond " $p<0.05$ ". The American Statistician. 2019;73(sup1):1-19.

31. Ristic M, Vlahovic Svabic M, Sasic M, Zelic O. Clinical and microbiological effects of fixed orthodontic appliances on periodontal tissues in adolescents. Orthod Craniofac Res. 2007;10(4):187-195.

32. Saravanan S, Kalyani V, Vijayarani MP, et al. Caries prevalence and treatment needs of rural school children in Chidambaram Taluk, Tamil Nadu, South India. Indian J Dent Res. 2008;19(3):186-190. 
medRxiv preprint doi: https://doi.org/10.1101/2021.03.24.21253842; this version posted March 26, 2021. The copyright holder for this preprint (which was not certified by peer review) is the author/funder, who has granted medRxiv a license to display the preprint in All rights reserved. No reuse allowed without permission.

33. Kirthiga M, Murugan M, Saikia A, Kirubakaran R. Risk Factors for Early Childhood Caries: A Systematic Review and Meta-Analysis of Case Control and Cohort Studies. Pediatr Dent. 2019;41(2):95-112.

34. WHO. Guideline: sugars intake for adults and children. World Health Organization; 2015.

35. Marí JAT. Hidden sugar in food: A. risk for health. J Clin Nutr Diet. 2017;3:1-3.

36. Pitts NB, Zero DT, Marsh PD, et al. Dental caries. Nature reviews Disease primers. 2017;3(1):1-16.

37. Klein H, Palmer CE. Studies on dental caries: VII. Sex differences in dental caries experience of elementary school children. Public Health Reports (1896-1970). 1938:1685-1690.

38. Patir A, Seymen F, Yildirim M, et al. Enamel formation genes are associated with high caries experience in Turkish children. Caries Res. 2008;42(5):394-400.

39. Vieira AR, Marazita ML, Goldstein-McHenry T. Genome-wide scan finds suggestive caries loci. J Dent Res. 2008;87(5):435-439.

40. Rose SR, Municchi G, Barnes KM, et al. Spontaneous growth hormone secretion increases during puberty in normal girls and boys. J Clin Endocrinol Metab. 1991;73(2):428-435.

41. Martinez-Mier EA, Zandona AF. The impact of gender on caries prevalence and risk assessment. Dent Clin North Am. 2013;57(2):301-315.

42. Lukacs JR, Largaespada LL. Explaining sex differences in dental caries prevalence: saliva, hormones, and "life-history" etiologies. Am J Hum Biol. 2006;18(4):540-555.

43. Campus G, Solinas G, Cagetti MG, et al. National Pathfinder survey of 12-year-old Children's Oral Health in Italy. Caries Res. 2007;41(6):512-517.

44. Alonge OK, Narendran S. Periodontal health status of school children in St. Vincent and the Grenadines. Odontostomatol Trop. 1999;22(88):18-22.

45. Preisser JS, Das K, Long DL, Divaris K. Marginalized zero-inflated negative binomial regression with application to dental caries. Stat Med. 2016;35(10):1722-1735.

46. Bassani DG, da Silva CM, Oppermann RV. Validity of the "Community Periodontal Index of Treatment Needs" (CPITN) for population periodontitis screening. Cad Saude Publica. 2006;22(2):277-283.

47. Oh TJ, Nam OH, Kim MS, Choi SC, Lee HS. Oral Health of Patients with Special Health Care Needs After General Anesthesia: A 25- Year Retrospective Study. Pediatr Dent. 2018;40(3):215-219.

48. Zhou N, Wong HM, McGrath C. Oral health and associated factors among preschool children with special healthcare needs. Oral Dis. 2019;25(4):1221-1228.

49. Children's Dental Health Survey 2013. Report 2: Dental Disease and Damage in Children

England, Wales and Northern Ireland. 2015. https://digital.nhs.uk/data-andinformation/publications/statistical/children-s-dental-health-survey/child-dentalhealth-survey-2013-england-wales-and-northern-ireland. 